\title{
New Perspectives on Foreign Language \\ Teacher Education
}

\section{Chang, Kyung-Suk (T aejon National University of Technology)}

\section{Introduction}

It has been widely believed that teachers teach as they were taught. Most teachers have had many years of being taught as students and have absorbed teacher-centered concepts of education. Therefore, it is not surprising that they tend to fall back on the traditional model of education. How, then can this situation be changed? There is no simple panacea. However, there has been a number of changes in foreign language teacher education that are likely to lead toward the improvement of teaching in the long term.

While there is a considerable body of literature on language teaching methodology, there is a relatively small literature on language teacher education. The scanty literature shows that the complexity of roles and tasks of teachers has increased rapidly over the last few decades. This is particularly true of foreign language teachers in our context.
The traditional approach to language teacher education has been questioned in terms of the long-term teacher development. The new paradigm has emerged with a great deal of emphasis on long-term teacher development. The present study aims to articulate a theoretical framework for the field of foreign language teacher education. We also look at new perspectives on language teacher observation and supervision within the paradigm shift of approaches to teacher education. The study further provides some implications for foreign language teacher education curriculum and syllabuses in our educational context.

\section{A Paradigm Shift: From}

\section{training to development views}

The paradigm shift of approaches to teacher education is summarized in Table 1.

< Table 1> The paradigm shift of language teacher education

\begin{tabular}{|c|c|}
\hline training-centered traditional View & devel opment-cent ered cur rent View \\
\hline delivery mechanism & learning process \\
\hline skil1/t echnique & at t itude/ awar eness-based, \\
\hline knowl edge- bas ed & towards personal growth/devel opment \\
\hline compet ency-based & hol ist ic \\
\hline product/ certificate weighted & process weighted \\
\hline means one can get a job / promtion & means one can stay interested in one's job \\
\hline short term & long term \\
\hline one- of $\mathrm{f}$ & ongoing / cont i nual \\
\hline compul sor y & vol unt ary \\
\hline top- down approach to change & bot tom up approach to change \\
\hline external agenda & internal agenda \\
\hline mostly done with experts & can be done with self/peers \\
\hline trainer-cent ered syllabus & trainee-cent ered syllabus \\
\hline $\begin{array}{l}\text { teacher's passive role in } \\
\text { theory-building/ } \\
\text { recipients of change }\end{array}$ & $\begin{array}{c}\text { teacher's active role in theory-building/ } \\
\text { subjects of change }\end{array}$ \\
\hline
\end{tabular}


Some issues from Table 1 deserves more attention than others. They will be further discussed in the following sections. This does not mean that changes in other areas are not important.

\section{From delivery to development}

Richards (1997) makes a distinction between delivery mode and development one in foreign language teacher education. While knowledge and skills in the traditional mode are delivered directly from trainers to teachers, teachers in the developmental mode are required to take an important role in their professional development. It is teachers themselves that are responsible for their own learning. More recently, those involved in language teacher education are more concerned with hows than whats. Its underlying assumption for the development mode is to encourage teachers to learn from their own teaching experience (Richards \& Lockhart, 1994; Wallace, 1991).

In a more complicated way, Freeman (1982) categorizes teaching into four aspects: knowledge, skill, attitude and awareness. Whatever stage of the career a teacher belongs to, there are a great number of things are inside her or his teaching: language knowledge, a variety of techniques, different sorts of values, attitudes towards society, schools, pupils and other colleagues.

Knowledge and skills required for teaching are delivered at the initial stage of teacher training, where trainees need to acquire basic knowledge and skills. At this stage, much focus is given to teaching as scientific knowledge and theory. As teacher training moves forwards, the delivery aspect becomes less and development becomes more important.

More attention is paid to attitude and awareness in the development mode. In the long term, development aspect is crucial in triggering awareness of what the teacher is doing and why. Without raising awareness, other sub-categories of teaching might be easily taken as a routine. Therefore, it is assumed that raising awareness could trigger teachers' spirit of inquiry into their own teaching experience. Teacher growth and development is an on-going developmental process, beginning early teacher training programs and continuing throughout a teacher's career.

In spite of the importance of development, the argument here is not necessarily that the delivery mode should be excluded out of language teacher education. The point of the discussion is that delivery and development should go hand in hand to be fully effective, for teaching is not a technical practice rather a complex decision-making process based on four key aspects of teaching: knowledge, skill, attitude and awareness.

\section{Traine -centered curriculum}

Perspectives on foreign language teaching have recently shifted from being product-oriented and from teacher-centered to being learner-centered. This recent movement is also what has happened in language teacher training classrooms. There is a parallel between language classrooms and teacher training classrooms. This is shown in the stacks in Figure 1(adapted from Woodward, 1991). That is, the approach to language teacher training has moved from being trainer-centered to being trainee-centered and from being theory-based to being theory-building in practice. Within the parallel mode of Figure 1, teacher trainees in the training classroom need to be taught as students are taught in the language classroom. As teachers take various roles in the language classroom, the roles of trainers in the training classroom are varied from class dominator to material provider, guide, facilitator and scaffolding giver. 
[Figure 1] A parallel stack of teaching and training classrooms

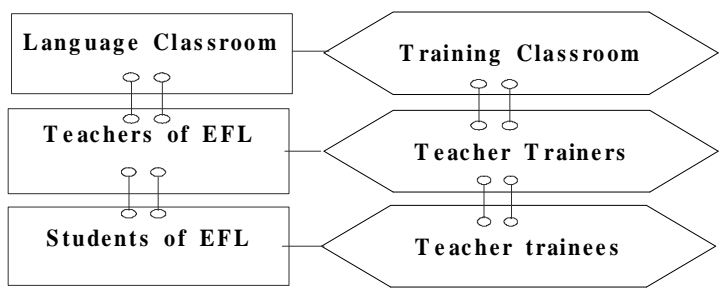

Along with focus on learner and trainee perspectives in the language and training classroom, there has been increasing emphasis on differences in individual cognitive learning styles. Emphasis on differences in trainees' learning styles has lead trainers to the question: What kind of supervisory modes should appropriately be taken for different trainees with various cognitive styles? While the learner-centered approach to language teaching calls for teachers' better understanding of learners' needs, beliefs and variety, there is need for trainers' better understanding of trainees' expectations, needs, and attitudes and individual differences in learning styles. As mentioned earlier, it is implied that roles trainers assume in the training classroom have become complicated just as those of teachers in the language classroom have.

\section{The reflective model of teaching}

The term 'reflective teaching ' has become part of foreign language teacher education. Reflection is often proposed as an important ingredient in most teacher training courses, sometimes even as a defining characteristic of good teaching (Elbaz, 1988). Zeichner (1981-82) points out, reflection is an essential characteristic of teaching particularly if one is concerned about school improvement and reform. Teachers' self-reflection is emphasized as a prerequisite to their professional own development. The reflective perspective on teaching encourages teachers to become aware of their own learning and to respond to various issues dynamically. This means that teachers are encouraged to bring a problem within their own teaching to a conscious level of awareness. The enhancement of awareness is crucial to the ongoing monitoring, changes in teaching and the effects of the changes.

How is awareness raised? One of possible answers is that it can be fostered through journal writing. According to Bailey (1990), journal writing may be defined as a first-person written account of experience. The nature of self-discovery of writing might be implemented into self-inquiry into daily teaching. Teachers write about teaching and at the same time they are actively involved in reflecting on daily teaching. During the process of writing journals and reading them, teachers might find out some salient problems and seek solutions. Problems are various as they come out all different stages and contexts of teaching. For example, they might be

- Why do I do this?

How will I group the class?

Why does not this method work in my class?

What do I do with the less able students?

Teachers may link the present issues with the past teaching experience, seeking solutions. This is analogous to Wallace's(1991) reflective teaching linked with experiential knowledge. It is likely that teachers face problems unexpected in a certain situation, or one solution may generate another problem. A circle of self-inquiry into teaching goes on and on as long as teachers reflect on their records of what happens in the class and in himself as a teacher. By doing systematic investigation into their journals, teachers become classroom researchers. As Holly (1989) argues, daily teaching easily can be unconscious and automatic without teachers systematic self-critical inquiry. Teacher-initiated classroom 
research also might lead to effective changes in classroom teaching, however small. From the reflective view of teaching and teacher education, individual teachers are seen as agents of change (Dufficy, 1993:93).

\section{Action research: Teachers as theory discoverers}

A wide variety of strategies can be used for professional development. One effective way is for teachers to carry out action research. Kemmis and McTaggart (1988:5) define action research as a form of collective self-reflective inquiry undertaken by participants in social situations. It is carried out mostly to improve the rationality and justice of their own social or educational practices, as well as their understanding of these practices and the situation which these practices are done. Problems or issues in a certain context give rise to questions. Through the process of action research the problems can be solved by using various kinds of evidence in a reasoned way.

Fundamental to the recent action research movement is the argument that teacher-initiated classroom research is an effective way to bridge the gap between theory and practice. As Chang and Beaumont (2000) note, the principle is that research by teachers should grow out of the problems and issues which confront them in their daily work and the outcomes of such research therefore feed directly back into the classroom. Ramani(1987) also shows the way teachers can move towards 'theory discovery' through investigating issues they are interested in, thus making theory relevant to their everyday teaching. In this process, action research may contribute to the overall research base, but in essence it is more concerned with teacher development than it is with the generation of hard data (Wallace, 1998; Burns, 1999). In this token, action research supports the process of teachers' critical reflection on teaching. Crooks (1993) also points out that by conducting action research, teachers find themselves with the potential to be a major component in the continuing efforts to improve their own teaching. At the very core of action research is the assertion that teacher-initiated research leads to teacher development

\section{Language Teaching Practice and Observation}

\section{Teaching practice component}

In spite of change in our teacher training context over the last two decades, we still face many problems which place obstacles in the way of language teacher education. One of the most serious problems is that most of our teacher training courses tend to give priority to knowledge on language itself, theory on teaching methods, language improvement and the assessment of trainees on these components. These components tend to be handled in a trainer-centered way, where trainees are treated as receiver of knowledge. However, this does not necessarily mean that language knowledge and theory on methodology are less important than other components. Problem lies in unbalanced stress on those components and in the way of training.

\section{1) More focus on teaching practice}

It is true that we can learn a lot about teaching by talking about teaching, materials and techniques, but we cannot really learn about teaching without actually doing it. There are a lot of benefits in teachers' being able to practice teaching in a supportive atmosphere. Among them are (Gower \& Walters, 1991):

- to provide teacher trainees with an opportunity to try out techniques;

- to provide teacher trainees with an 
opportunity to have their teaching evaluated and constructively criticized by trainers, other trainees and themselves;

- to encourage in them some criteria for self- evaluation;

- to help them develop their own teaching styles; and

- to develop in them an awareness of how the language is used effectively in the language classroom.

Although teaching practice such as micro-teaching has been introduced in some training courses, teaching practice is still neglected in most training settings. For example, four different English language teacher training courses are analyzed to see which components the teacher training courses are composed of and how much focus is given to each component.

\section{[Figure 2]}

\section{Components of Teacher Training Course}

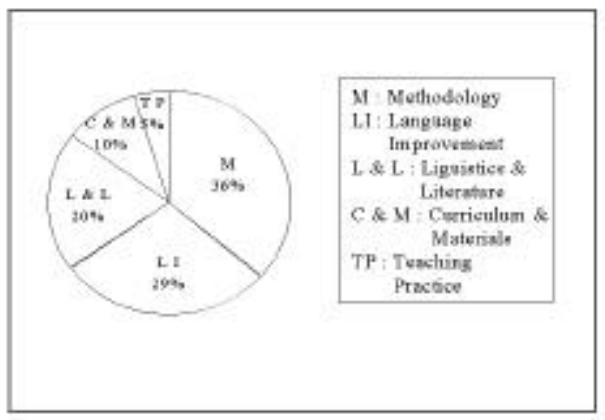

As Figure 2 shows, heavy focus is given on theoretical background on language and methodology. This might leave a big gap between theory and practice. This is likely to be one of the most serious problems we have faced in the current language teacher education. More attention need to be paid to 'teaching practice' component in teacher training courses. By doing this, teachers can be encouraged to put theory from the course into practice. Then their teaching is more likely to improve through critical thinking, which benefits teachers and their self-development in the long term.

\section{2) Process-oriented evaluation of teaching practice}

Another problem related to teaching practice is how it should be evaluated to help teachers get the best out of it. The evaluation of teaching practice, if any, has been done in the trainer-centered model, where teacher trainees' teaching is evaluated as a one-off activity. It is very often evaluated in a threatening atmosphere as it is done only once for assessment. It is not done a continuous and developmental activity. Problem lies here. Evaluation should not be the end itself but a means to help trainees to change for better teaching, however little.

Here it is suggested that trainers, trainees and other trainees be involved in the process of evaluation, a cooperative model of teaching practice evaluation. Figure 3 shows the cooperative model where three parties are involved in the evaluation process.

\section{[Figure 3]}

Cooperative relationship in $\mathrm{T} P$ Evaluation

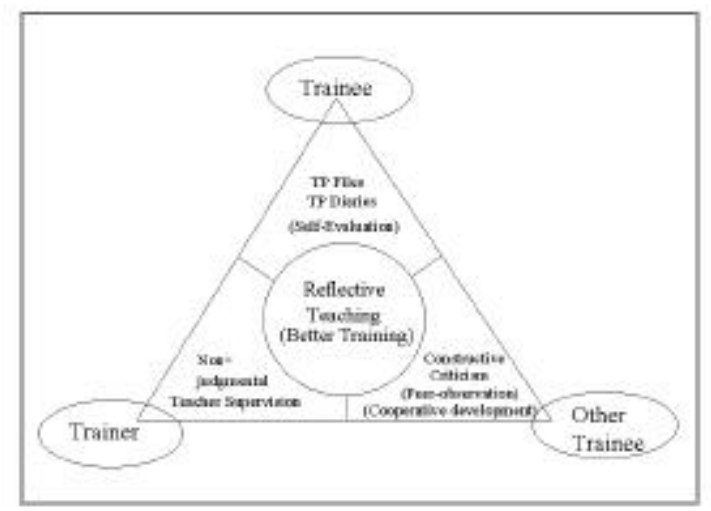

First, teacher trainees are invited to the evaluation process. As teaching is a personal skill and in many areas individual teachers have to work out the best way for themselves, it is valuable for trainees to evaluate their own teaching. One of the ways of doing that is to encourage teachers to keep teaching practice 
files as the course goes on. The file might include lesson plans, reflections on their own teaching, copies of trainer's comments, examples of materials and aids used, sources of ideas etc. As pointed out earlier, it is worth keeping a personal diary of teaching practice where teachers reflect on their daily teaching practice.

Second, the trainer, as a supervisor, is in a position to help with lesson preparation and teaching, to observe critically teaching and to give helpful feedback. What is important in the cooperative model is non-judgemental approach to teacher supervision. The role the trainer takes in the non-judgmental model is not just an authority figure who assesses teachers' performance. Judgmental teacher supervision tends to be done in a very threatening atmosphere and mutual communication between trainer and trainee is very limited. Unlike the judgemental approach, non-judgmental supervision can provide key conditions in which teachers are encouraged to express their own reflections and self-evaluation. It is important to provide trainees with feedback on problem areas in need of correction or improvement.

Third, other trainees are an extremely useful resource of feedback. They can offer criticism about language, materials and skills, but it needs to be done with sensitivity. Some comments need to be avoided if they are likely to provoke a defensive reactions and not helpful for future relationships. Accordingly, openness, trust and understanding among trainees should be highly valued in the cooperative process of evaluation.

\section{Teacher observation}

Teacher observation is one of the most important aspects of language teacher education. It is not until recently that we have become more aware of observation as a learning tool in teacher education. The underlying premise of the awareness is that observation is a tool for developing capable and creative teachers.

\section{1) Different types of teacher observation and supervision}

Wajnryb(1992:1ff) notes that observation can serve a number of people in a number of contexts towards a number of different ends. There seems to be three elements, which most observation include: training, development and as ses sment.

\section{(1) Observation and supervision for training}

Observation for the purpose of training is most typically, although not exclusively, seen on a pre-service training course. For example, a trainee observes a trainer teaching as 'modelling' experience and, in reversed roles, the trainee is observed trying some procedures he or she has observed or been told about in the course. Maingay (1988) describes an observer involved in observing for training as a provider of a scaffolding to support a new teachers. From a simplistic view, where training is the main purpose of observation, it seems to be the case that prescriptive and directive feedback is provided. The trainee is told what he is doing right or wrong, that is whether performance is done in the trained and supposedly appropriate way. The observer informs the teacher about what should and should not be done.

\section{(2) Observation and supervision for assessment}

Observation for assessment purposes can be carried out during the training course, in the middle of the course, or at the end of the course. Particularly, it is predominant at the end of a pre-service training course, when the assessor has to recommend pass or fail (Maingay, 1988). The assessor may come from 
within or from outside the training institution.

It has been pointed out that observation for assessment has some negative aides. First, as is so often the case, the question of assessment causes feelings of anxiety in teachers because their performance is judged. The additional presence of an observer as assessor tends to affect the behavior of the teacher under assessment. In this type of observation, the trainee teacher gets nervous, particularly when something goes wrong.

In addition, the lesson for assessment tends to be a one-off display, an isolated performance. This leads to an unhealthy emphasis on displaying teaching skills for one lesson only. It may be necessary to develop skills to cope with one lesson and to master techniques, but that is not sufficient. Lessons are not isolated events; rather they are part of a process.

Maingay (1988:128) proposes some steps to improve those negative sides of observation for assessment. Firstly, teachers need to understand clearly the particular scheme of observation, feedback and assessment. Secondly, feedback with focus on support rather than on criticism should be provided. More importantly, it is suggested that assessment run through a course and not be simply tacked onto the end. In other words, focus should be given not to assessment of individual lessons, but to the development of a trainee over the whole course. In a way, it is assumed that reduced tension would be spread over a long period although it is impossible to escape the tension of assessment altogether.

\section{(3) Observation and supervision for development}

Observation as a learning tool is a recent development in the literature of teacher education. Observation plays an important in making teachers think about what they do and be aware of the reasons for teaching in a particular way. Where observation is carried out for development, observation should be regarded as a stimulus to reflection and to evoking professional awareness (Haycraft 1988).

Maingay(1988:118) makes a distinction between 'ritual teaching behavior' and 'principled teaching behavior'. The former refers to teaching behavior that is unthinking and divorced from the principles behind it. On the other hand, the latter is described as teaching behavior that is informed by the reasons for doing something that the teacher is aware of. It is very likely that observation for development can lead teacher away from unthinking teaching toward principled teaching. In the observation for development purposes, the main focus is on re-examining what has been taken for granted and become ritualized. Through the observation, the principles behind rituals are made clear to teachers, so that rituals can generate fresh behaviors (Maingay 1988).

Where teachers are observed for development purposes, the observer takes a role as developer, different from trainer. The role of the observer as developer is crucial in drawing attention to the principles behind unquestioned rituals of teaching. The main focus in providing feedback is on suggestion and exchange of ideas; but above all, on developing the teacher's self-appraisal skills. Wajnryb(1992:22) suggests that the observer should avoid being judgemental in a way that reinforces the power invested in his position and the powerlessness of the trainee. The observer should consider his/her role as one facilitating growth rather than giving information, answers or solutions. This type of developmental feedback is more difficult to frame than the prescriptive and directive feedback given in observation for training.

Here, it should be made clear that observation for training, development and assessment are not discrete. It seems to be the case that most observations include those three elements. It is 
rare for an observation to be for training pure and simple, or for development alone. Observation is rarely for one purpose only, often for two and frequently for all three together.

\section{IV . Implications for Foreign \\ Language Teacher Education}

\section{Curriculum}

\section{Collaborative partnerships in language teacher education}

University-based per-service language teacher education is faced with the critical question: What can the university do better than the schools in preparing teachers? Indeed, many teacher educators have always believed that school-based experience plays an important, central part of the pre-service teacher education. It is suggested that school-based teacher education provide student teachers with working with practising teachers, increasing amount of school-based experience. However, it is the balance that is being considered. School-based programs are perceived to be more practice oriented and focus directly on the needs and requirements for teaching in particular situations. There is no doubt about the value of student teachers' direct learning experience in schools. The trend toward more time devoted to field-based experience is based on the underlying assumption that practical experience necessarily contributes to the improvement of teaching(Tabachnick et al., 1980). This brings the need for developing programs that link school-based experience with reflective teaching for the improvement of teaching.

There is a strong need for developing preparation programs in which classroom teachers, in partnership with university faculties, are prominently involved in language teacher education. It is recognized that classroom teachers have a significant impact on the learning of student teachers and in shaping their beliefs and practices. Within the school and university partnership to improve teaching and teacher education, we see dimensions of the role of classroom teachers as trainers. Classroom teachers work as mentors in teacher education programs. They are committed to improving teacher education and willing to devote time for study and practice in mentoring student teachers (Roth, 1994).

Nevins(1994:31) states that the primary goals of the mentor teacher component are to build connections between university and field experiences and to develop a role supporting mentoring rather than more conventional supervising. Mentor teachers help student teachers see benefits in reflective teaching. It is recognized that experienced teachers use the wisdom of practice to help student teachers develop an ability to reflect on instructional decisions through constant questioning.

Meanwhile, the role of the university in such collaborative partnerships is a provider of theoretical perspectives that enable trainees to work through principles. This helps student teachers re-base their experience on their received knowledge within a reflective model. In this way, the cooperation between university and schools in teacher education can be achieved.

\section{Attitude development in pre-service teacher education}

Teacher education should be a long-term process which starts in university pre-service and lasts throughout the career. The aspect of teacher development gained ground not only in in-service, but also pre-service teacher education. Pre-service teacher education programs need to be increasingly concerned with providing opportunities for student teachers to become conscious of the ways in which they 
perceive and act upon information during teaching practice. Johnson(1992) notes that the goal of these opportunities is for them to understand not only what they do but also why they do it. Through this reflective attitude tow ard teaching, student teachers learn to handle various unpredictable situations effectively for which they have had no training. Then, student teachers can be ready to take more independent responsibility for teaching.

It has been argued that the concept of reflective teachers should be introduced in student teachers' teaching practice(Pennington 1990; Zeichner 1980; Zeichner and Liston 1987). It is acknowledged that attention should be paid to attitude and awareness development at the very beginning of the pre-service training. It is important that trainee teachers acquire the basic skills and techniques for teaching; at the same time, attitude development and change through reflective teaching should be emphasized in pre-service training context, for it is crucial as the basis for continuing professional growth.

Dufficy(1993) suggests that teacher educators should seek to provide student teachers with a framework in which to learn actively during their initial teaching experience. Within the framework, student teachers are encouraged to develop a commitment to learning to teach. The sense of engagement leads student teachers to find their own part in making decisions through reflecting on teaching experience. It is possible that a student teacher reaches the end of the training course and becomes a teacher without such engagement. Without the engagement, as Dufficy(1993) argues, it will be less certain what has been learned and far harder for the teacher to continue his own professional development. The sense of engagement is closely related to attitude development.

\section{More emphasis on syllabuses for aw areness-raising}

As mentioned earlier, aw areness is one of the most important aspects in teacher development. There has been a strong need for syllabuses which help teachers raise their awareness and change their attitudes. One way of doing that is to introduce journal writing to the training course. Along with second language learning, journal writing has been carried out in second language teaching ( for example, Deen 1987; Telatnik, 1977 \& 1978, quoted by Bailey,1990). The findings of the studies provide some meaningful insights into defining effective teaching. They are important as they reveal what is actually happening inside the classroom and teachers, however not all. In line with the recent emphasis on reflective practitioner(see Schön, 1983), attention has been paid to journal writing as a means of exploring own teaching practice.

Journal writing have some far-reaching implications into language teaching and teacher education. First, the close examination of journals by teachers might provide important information on teacher effectiveness and defining qualities of a good teacher. To go further, the findings can also be useful in setting up preor in-service teacher training courses. Second, teachers may bring about some changes in practice through journal writing. There has been a huge gap between theory and practice. Through journal writing teachers get involved in systematic inquiry into their own teaching. They are not simply recipients of theory from outside schools but they are researchers into their own classes. It is very likely that teacher-initiated classroom inquiry bridges the big gap between theory and practice. Third, in terms of cooperative development, teachers can learn from colleagues through journal writing based on openness, willingness and candidness. A teacher in a school observes his/her colleague 
teachers' classes and keeps a record of the observation. Teachers might learn a lot from analysis and discussion on entries from the journals kept by their colleagues. However, this is not easy at all as teachers can be easily raged upon colleagues' criticism on what they have done during the class. This need to be done openly under the assumption that teachers might have less chance for professional growth unless they are willing to do what is required to be a professional.

\section{Support for teacher research}

Despite its claims to be teacher friendly, action research continues to be a minority interest in which teachers participate, either as part of a course or program undertaken in collaboration with higher education institutions. If action research is to become recognized as a means of every teacher's lifelong development, then it needs to be a part of every school's development plan for improvement.

However, in our context, language teaching is developing against a background of institutional and classroom constraints that inhibit change, creating a basic concern about the feasibility of individual teacher development within such context. In our system, the top-down approach to language teacher education frequently fails to bring about changes in language education. In consequence, there is an increasing demand for the active participation of classroom teachers in change process. As Chang and Beaumont (2000:84) claim, it is crucial to develop sensitive and supportive environments in which teachers can improve their professional lives by having confidence to change. To meet such a strong need, particularly in-service teacher training programs should have content and organization in which teachers play an active role.

\section{Conclusion}

Increasingly, the traditional model of teaching as a technical process has been challenged. Instead, efforts to conceptualize teaching in the reflective model provide the notion that teaching is more than a collection of skills or techniques. It is noted that the emerging language teacher education encourages teachers not merely in the mastery of rules of practice but in an exploration of knowledge, beliefs, and thought that informs such practice. In line with the paradigm shift, the current foreign language teacher education needs to reorient away from training toward one that seeks a more holistic approach to teacher development. It is suggested that those involved in language teacher education should explore various ways of encouraging teachers to be actively involved in reflective teaching. In the long term, this will serve as the ground of the establishment of foreign language education and teacher education.

\section{References}

Bailey, K. (1990). The Use of Diary Studies in Teacher Education Programs. In J.C. Richards \& D. Nunan (Eds.). Second Language Teacher Education. (pp.215-226). Cambridge: Cambridge University Press.

Burns, A.(1999). Collaborative Action Research for English Language Teachers. Cambridge: Cambridge University Press.

Change, K. S. \& Beaumont, M. (2000). Writing to Learn: A bottom-up approach to in-service teacher education. In M. Beaumont \& T. O'Brien (Eds.). Collaborative Research in Second Language Education. (pp.83-94). Trentham Books: England.

Crooks, G. (1993). Action Research for Second Language Teachers: Going beyond teacher research. Applied Ling uistics, 14(2), 131-144.

Dufficy, P.J. (1993). The Pedagogy of 
Pre-service TESOL Teacher Education. Journal of Education for Teaching, 19(1), 83-96.

Elbaz, F. (1988). Critical Reflection on Teaching: Insights from Freire. Journal of Education for Teaching, 14(2), 171-181.

Freeman, D. (1982). Observing teachers: Three approaches to in-service training and development. TESOL Quarterly, 16(1), 21-28.

Gowers, R. \& Walters, S. (1983). Teaching Practice Handbook. Oxford: Heinemann.

Holly,M.L.(1989). Reflective Writing and the Spirit of Inquiry. Cambridge Journal of Education, 19(1), 71-79.

Johnson, K.E. (1992). Learning to Teach: Instructional actions and decisions of preservice ESL teachers. TESOL Quarterly, 26(3), 507-535.

Kemmis, S. \& McTaggart, R. (1988). The Action Research Planner. (3rd Edition). Victoria: Deakin University Press.

Maingay, P. (1988). Observation for Training, Development or Assessment? In T. Duff (Ed.). Explorations in Teacher Training: Problems and issues. (pp.118-131). Essex: Longman.

Nevins, R. (1994). Fading to a Whisper: One mentor's story of sharing her wisdom without telling answers. Journal of Teacher Education, 45(1), 31-45.

Pennington, M.C. (1990). A Professional Development Focus for the Language Teaching Practicum. In J.C. Richards \& D. Nunan (Eds.). Second Language Teacher Education. (pp.132-151). Cambridge: Cambridge University Press.

Ramani, E. (1987). Theorizing from the Classroom. English Language Teaching Journal, 41(1), 3-11.

Richards, J. C. (1997). B eyond Training. Cambridge: Cambridge University Press.

Richards, J.C. \& Lockhart,C. (1994). Reflective Teaching in Second Language Classroom. Cambridge: Cambridge University Press.

Roth, R.A. (1994). The University Can't Train Teachers?: Transformation of a profession.
Journal of Teacher Education, 45(4), 261- 268.

Schön, D. (1983). The Reflective Practitioner. London: Temple Smith.

Tabachnick, et al. (1980). Teacher Education and the Professional Perspective of Student Teachers. Interchang e, 10(1), 12- 29.

Wajnryb, R. (1992). Classroom Observation Tasks. Cambridge: Cambridge University Press.

Wallace, M. (1991). Training Foreign Language Teacher: A reflective approach. Cambridge: Cambridge University Press.

Wallace, M. (1998). Action Research for Language Teachers. Cambridge: Cambridge University Press.

Woodward, T. (1991). Models and Metaphors in Language Teacher Training: Loop inp ut and other strategies. Cambridge: Cambridge University Press.

Zeichner,K.M.(1980). Myths and Realities: Field-based experiences in preservice teacher education. Journal of Teacher Education. 31(6), 45-55.

Zeichner,K.M. (1981-82) Reflective Teaching and Field-Based Experience in Teacher Education. Interchange, 12(4), 1- 22.

Zeichner, K.M. \& Liston,D.P. (1987). Teaching Student Teaches to Reflect. Harvard Educational Review.. 57(1), 23-48. 
초록

\section{외국어 교사 교육과정의 새로운 방향 모색 \\ 장 경 숙 \\ (대전 산업대학교 교수)}

\begin{abstract}
과거 외국어 교사연수는 언어에 관한 지식 전달 위주로 이루어졌다. 외국어 교사가 되기 위해서 는 연수 담당자(trainer)로부터 전수된 배경지식을 익히고 해당 언어를 가르치는데 필요한 몇 가지 기본 기능이나 기교에 능숙해야만 했다. 그러나 장기적인 안목으로 볼 때 교직은 반드시 교과목에 관한 기본 지식과 기교로만 이루어진다고 볼 수 없다. 이런 기본 요소들은 교사가 교직 생활을 시작하면서 곧 교직 생활의 일부가 되어 기계적으 로 이루어지기 쉽다. 교사가 교직 생활로부터 활 기를 찾고 새로운 것을 추구해 나가기 위해서는 자신과 동료의 수업을 관찰하고 수업장학(teacher supervision)을 통해 자신과 상대방의 수업을 분석 하고 건설적인 비판을 통해 교수와 학습에 대하여 끊임없이 연구해야만 한다.
\end{abstract}

교사의 이런 자발적인 태도는 장기적인 안목으로 볼 때 교사개발(teacher development)로 이어질 수 있다. 또한 교사는 주어진 여건에서 문제점을 찾아 해결책을 모색하는 현장연구(action research)를 통해 교사개발을 성취할 수 있다. 교 사일지(journal writing) 또한 교사가 자신의 교수 활동을 분석하고 성찰하는데 활용될 수 있다. 아 직까지는 지식 전달식 강의에 치중하고 있는 우리 의 외국어 교사교육 실정에서 교사 중심적인 성찰 교사교육(reflective teacher education) 모형이 시 급히 도입되어 외국어 교사 양성과정과 일반 및 심화 연수과정에 효과적으로 반영되어야한다.

Key words: in-/pre-service teacher education, teacher development, reflective teaching, classroom research, action research, teacher observation, teacher supervision, journal writing 